\section{The hidden side of sustainable operations and supply chain management: unanticipated outcomes, trade-offs and tensions}

\author{
Stelvia V. Matos
}

Surrey Business School, Faculty of Arts and Social Sciences, University of Surrey, Guildford, UK

Martin C. Schleper

University of Sussex Business School, University of Sussex, Brighton, UK

Stefan Gold

Faculty of Economics and Management, University of Kassel, Kassel, Germany, and Jeremy K. Hall

Science Policy Research Unit, University of Sussex Business School, University of Sussex, Brighton, UK

\begin{abstract}
Purpose - The research is based on a critically analyzed literature review focused on the unanticipated outcomes, trade-offs and tensions of sustainable operations and supply chain management (OSCM), including the articles selected for this special issue.

Design/methodology/approach - The authors introduce the key concepts, issues and theoretical foundations of this special issue on "The hidden side of sustainable operations and supply chain management (OSCM): Unanticipated outcomes, trade-offs and tensions". The authors explore these issues within this context, and how they may hinder the authors' transition to more sustainable practices.

Findings - The authors present an overview of unanticipated outcomes, trade-offs, tensions and influencing factors from the literature, and identify how such problems may emerge. The model addresses these problems by highlighting the crucial effect of the underlying state of knowledge on sustainable OSCM decision-making. Research limitations/implications - The authors limited the literature review to journals that ranked 2 and above as defined by the Chartered Association of Business Schools Academic Journal Guide. The main implication for research is a call to focus attention on unanticipated outcomes as a starting point rather than only an afterthought. For practitioners, good intentions such as sustainability initiatives need careful consideration for potential unanticipated outcomes.

Originality/value - The study provides the first critical review of unanticipated outcomes, trade-offs and tensions in the sustainable OSCM discourse. While the literature review (including papers in this special issue) significantly contributes toward describing these issues, it is still unclear how such problems emerge. The model developed in this paper addresses this gap by highlighting the crucial effect of the underlying state of knowledge concerned with sustainable OSCM decision-making.
\end{abstract}

Keywords Sustainable supply chain management, Unanticipated outcomes, Trade-offs, Tensions, Literature review, Sustainability

Paper type Research paper

(C) Stelvia V. Matos, Martin C. Schleper, Stefan Gold and Jeremy K. Hall. Published by Emerald Publishing Limited. This article is published under the Creative Commons Attribution (CC BY 4.0) license. Anyone may reproduce, distribute, translate and create derivative works of this article (for both commercial and non-commercial purposes), subject to full attribution to the original publication and authors. The full terms of this license may be seen at http://creativecommons.org/licences/by/4.0/legalcode

Hidden side of sustainable OSCM 
IJOPM

40,12

\section{Introduction}

This paper explores the unanticipated outcomes, trade-offs and tensions in sustainable operations and supply chain management (OSCM), and how they may hinder our transition to more sustainable practices. With the world facing severe grand challenges such as climate change, deforestation, biodiversity loss, inequality, famine, labor exploitation, modern slavery and more recently global pandemics (George et al., 2016; Scherer and Voegtlin, 2020), consumers and other stakeholders increasingly expect firms to take responsibility for their actions. As a result, concepts such as corporate sustainability, the triple bottom line and corporate social responsibility (CSR) have become increasingly imperative in today's corporate environments, including those in the OSCM field (Hartmann and Moeller, 2014; Mena and Schoenherr, 2020).

As we discuss below, trade-offs and tensions tend to focus on economic criteria, rather than sustainability concerns, whereas unanticipated consequences that relate to unforeseen negative social and environmental factors are often underestimated. Although scholars and practitioners are aware that attempts to improve specific supply chain parameters will impact others, much less attention has been focused on how this affects sustainable OSCM. An implicit assumption is that the good intentions of adopting sustainable practices may come at a financial cost, but otherwise will inevitably lead to societal benefits. In practice, such good intentions may be undermined by highly complex interactions among the myriad of sustainability parameters, and thus difficult to identify (Matos and Hall, 2007; Reiner et al., 2015; Carter et al., 2020, Wontner et al., 2020; Ye et al., 2020). They may also be shaped by variances in ignorance and self-interest (Nath et al., 2020; Silvestre et al., 2020; Glover, 2020). Our key message is that unanticipated outcomes, trade-offs and tensions are inevitable, and thus should be ingrained in OSCM.

Given that supply chains have become globally omnipresent and by definition include many different actors, their analysis is critical for understanding the problems that they create, as well as how they can improve social and environmental conditions. Yet, despite the strong academic and professional recognition that infusing OSCM practice with sustainability is crucial (Meinlschmidt et al., 2018; Cousins et al., 2019; Zarei et al., 2019; Meqdadi et al., 2020), some scholars have acknowledged that real-world progress toward sustainability in OSCM has been modest (e.g. Pagell and Shevchenko, 2014; Shevchenko et al., 2016; Gold and Schleper, 2017). We address this lack of progress by suggesting that unanticipated outcomes, trade-offs and tensions in sustainable OSCM initiatives are often overlooked, yet necessary for advancing sustainable development.

In what follows, we present an overview of unanticipated outcomes, trade-offs, tensions and influencing factors, followed by a selected literature review on how they are treated within the sustainable OSCM discourse. We then discuss the various processes and contexts that underline OSCM decisions, followed by a summary of the papers presented in this special issue. Drawing on these studies, we then propose a model that explains the antecedents of unanticipated outcomes. We conclude with a brief outlook for future research.

\section{Unanticipated outcomes, trade-offs and tensions in sustainable OSCM}

Although reasons for the lack of sustainability progress in OSCM are multifaceted, one explanation within the literature is that there are inherent incompatibilities among sustainable development parameters, which are often ignored when they should instead be approached as a research starting point (Margolis and Walsh, 2003; Norman and MacDonald, 2004; Hahn et al., 2015; Van der Byl and Slawinski, 2015; Haffar and Searcy, 2017). Similarly, the dogmatic idea that improved environmental or social dimensions can be easily correlated with improved financial performance (i.e. the so-called business case/win-win solutions) is often oversimplified. Such perspectives rely on an instrumental logic that has largely 
hindered OSCM scholars in embracing economic tensions and trade-offs linked to sustainability, thus impeding substantial improvements and adoption (Pagell and Shevchenko, 2014; Gold and Schleper, 2017). This is somewhat surprising, given that seminal organization theories (e.g. Simon, 1962) and OSCM researchers have known for some time that efforts to improve specific parameters (in this case economic, environmental or social) will impact others (Matos and Hall, 2007; Hall et al., 2012; Reiner et al., 2015). Consequently, rather than an aberration or exception, trade-offs are normal and expected, and thus should be managed.

An angle that has drawn even less attention within the sustainable OSCM literature is that strategies and actions sometimes have both expected effects as well as unanticipated outcomes, that is, unintended, unplanned or unforeseen consequences. Interestingly, nonsustainability OSCM research seems to have a more visible focus on such outcomes than sustainable OSCM studies. Since at least the examination of the bullwhip effect (Lee et al., 1997), OSCM scholars have found unintended consequences in various contexts, such as purchase price variance (Emiliani et al., 2005), the modeling of equilibrium disclosure and pricing strategies (Guan and Chen, 2015), revenue sharing in the mobile value chain (Choi, 2018), price pressure on suppliers (Schleper et al., 2017; Carnovale et al., 2019) or the monitoring of agents through IT (Scott et al., 2020). Moreover, Jonsson and Holmström (2016) investigate (un)intended consequences from a broader conceptual perspective in their supply chain planning study and emphasize the need to present both evidence of intended outcomes (when things work as designed) and unintended ones (when they do not).

Anticipated negative outcomes have been extensively addressed in the supply chain risk management literature, although attempts to incorporate sustainability-related supply chain risks have been sparse (Foerstl et al., 2010; Hofmann et al., 2014; Miemczyk and Luzzini, 2019; Hajmohammad and Shevchenko, 2020). One exception is presented by Giannakis and Papadopoulos (2016), who identified unwanted, yet anticipated consequences of sustainable management practices. This could include greenhouse gas emissions, accidents and environmental damages during logistics and transportation, boycotts against a company's products, financial damages caused by environmental accidents, legal noncompliance or unethical behavior such as child/ labor, animal testing, price fixing, bribery allegations and patent infringements during financial crisis (Giannakis and Papadopoulos, 2016).

Concerns over unanticipated outcomes build on seminal work by sociologists and economists. For example, Merton's (1936) seminal paper on unanticipated outcomes of social purposive action, emphasizes that recognition of unintended consequences is a necessary first step when developing sound scientific analysis, allowing for structured treatment of such unintended outcomes. Stigler's (1975) theory of economic regulation specifically focuses on who gains and who loses (often unintentionally) from regulatory policy, which stems from the failure of considering the political-economic interactions of its processes. Williamson (1993) notes that demand for control, i.e. obsessive calculativeness, can have both anticipated effects and unanticipated dysfunctional consequences, which can only be mitigated once the unintended consequences are taken into consideration when modeling calculations. Here, we use the term (un) anticipated to account for both positive and negative environmental and social consequences, since not all intended outcomes are positive nor are all unintended negative.

Actions taken in response to the current coronavirus disease 2019 (COVID-19) pandemic offer a variety of negative and positive examples of unanticipated consequences, thus calling for more research (Sarkis, 2020, forthcoming). One widely discussed example relates to the effect of the pandemic on $\mathrm{CO}_{2}$ emissions. Increased $\mathrm{CO}_{2}$ emission is an example of expected, thus anticipated, negative impacts that has historically been necessary for industrial expansion and economic growth. In contrast, the COVID-19 lockdown led to unexpected positive opportunities to experiment with reduced emissions from traffic and manufacturing that can now be used to develop future pollution mitigation strategies (Le et al., 2020).
Hidden side of sustainable OSCM 
IJOPM

40,12

Interestingly, although one would intuitively expect increased home working to reduce individual $\mathrm{CO}_{2}$ footprints, research indicates that this is only a seasonal benefit. For example, UK employees working from home the entire year produce on average about $80 \%$ more $\mathrm{CO}_{2}$ than those working in an office, where reduced emissions from transport are offset by increased emissions from heating (WSP, 2020). This is consistent with Giannakis and Papadopoulos (2016), who found that reducing economic activity does not necessarily decrease supply chain-related carbon emissions. Finally, recent research also finds severe negative unanticipated outcomes related to the pandemic and $\mathrm{CO}_{2}$ emissions on the macrolevel as many countries invest into the fossil fuel economy to avoid devastating recessions as a consequence of the pandemic (Harvey, 2020). Unfortunately, this effect might eventually even outweigh all other positive unanticipated outcomes.

Another example of positive and negative unanticipated outcomes relates to the poaching and smuggling of illegal wildlife. Whereas the number of killed rhinos in South Africa decreased by $53 \%$ during international travel restrictions and lockdowns (AFP, 2020), the decline of ecotourism and the following loss of income led to a sharp increase in the poaching of lions, giraffes and even a silverback gorilla in Uganda (Maron, 2020).

The limited attention given to unanticipated outcomes might also be caused by OSCM scholars' implicit assumptions that transitioning from mostly economic criteria in decisionmaking to include environmental and social aspects will automatically and unambiguously reduce environmental impacts and improve social conditions. This may have been the case in early sustainable supply chain efforts, where "low hanging fruits" were readily available (Schmidt et al., 2017), although Newton and Harte (1997) have criticized the business literature for overemphasizing the "easy wins" early-on. However, within more complex environments it is necessary to recognize that well-intended practices and strategies aiming at sustainable development do not guarantee positive outcomes and typically exacerbate trade-offs. For example, the COVID-19 pandemic significantly tested the resilience and sustainability conflicts of current OSCM systems by highlighting on the one hand the flexibility of supply chain management, and on the other how focal companies in developed countries were buffered at the expense of weaker upstream supply chain stakeholders in developing regions (Trautrims et al., 2020). Yet, only few supply chain studies have explored the additional complication of integrating resilience and sustainability factors (e.g. Fahimnia and Jabbarzadeh, 2016; Zahiri et al., 2017; Fahimnia et al., 2018; Jabbarzadeh et al., 2018). Ivanov (2018), for example, found that sustainability measures such as single sourcing and reducing storage facilities negatively impact supply chain recovery after disruptions.

Besides ongoing pleas that trade-offs and tensions within sustainability are theoretically resolvable (at least in the mid-and long-term), sustainability management research has started to acknowledging conceptual trade-offs in recent years on a more fundamental level (Hahn et al., 2015). According to this "paradox view" on organizations (Hahn and Knight, 2019) and organizationally driven contributions toward sustainability (Hall et al., 2018), tensions are to be resolved, accommodated or at least accepted on various dimensions. This can be, among others, between (1) social, environmental and economic aspects; (2) long- vs short-term perspectives; (3) intra- and inter-generational interests and (4) meso and macro agendas. Acknowledging and managing tensions is crucial for not getting stuck with overly timid measures that claim to meet all sustainability performance aspects at once (Varsei et al., 2014). It is thus even more remarkable, that a discipline such as OSCM that has a long and strong tradition of debating and investigating trade-offs between core performance dimensions such as flexibility, costs, quality, delivery time, dependability, etc. (cf. for example Ferdows and De Meyer, 1990; Hallgren et al., 2011; Vanpoucke et al., 2014; Wurzer and Reiner, 2018), tended to largely overlook these tensions and trade-offs when it comes to sustainable OSCM.

Other examples of the paradox view include Evenson and Gollin's (2003), Hall et al.'s (2008) and Pingali's (2012) examination of "Green Revolution" technologies in agriculture, originally 
pioneered by Nobel Peace Prize winner Norman Borlaug. They show that innovations vastly increased productivity but inadvertently increased environmental degradation and widened interregional social disparities in developing countries where, for example, farmers migrated to urban areas with low employment opportunities. In agricultural biotechnology, advocacy pressures targeting large agricultural biotechnology firms such as Monsanto resulted in high regulatory barriers, creating monopolistic tendencies that favored the large multinationals at the expense of smaller firms and public institutes attempting to develop more sustainable crops (Hall et al., 2018).

By investigating the supply chain position as an overlooked contextual variable in research on the link between sustainable OSCM and performance, Schmidt et al. (2017) find that companies that are closer to end consumers show higher levels of sustainable OSCM engagement. More surprisingly however, the performance gains for companies tend to decrease with higher proximity toward end consumers, a phenomenon they call the "supply chain position paradox" and which has - among other results - recently been confirmed by Mena and Schoenherr (2020).

Similarly, in healthcare operations, the implementation of patient care information systems increased medical errors rather than to reduce their likelihood (Ash et al., 2004). In international and regional policy, unanticipated consequences of voluntary labeling included higher food prices, worsening the position of women and displaced local production (Oosterveer et al., 2014).

While the above literature review outlines the importance, key issues, influencing factors and definitional constructs of (un)anticipated trade-offs and tensions from sustainability, the next section provides a more systematic review of how these issues are treated within the OSCM discourse.

\section{Sustainability OSCM research addressing trade-offs, tensions and unanticipated outcomes}

In order to better grasp the literature on unanticipated outcomes, trade-offs and tensions at the broader intersection of OSCM and sustainability/CSR, we conducted a literature review using Scopus, with the following search string on keywords, abstracts and titles of business and management publications published in English in peer-reviewed journals: ("supply chain*” OR “operations") AND ("sustainab*” OR "CSR" OR "responsibility" OR "green”) AND ("tension" OR "trade-off*" OR "unintended" OR "unanticipated").

The initial search revealed a total of 274 papers. We then scanned through the abstracts and excluded all publications that were literature reviews or, and those that did not clearly focus on the abovementioned topics. We also excluded studies from journals ranked lower than " 2 " on the current Academic Journal Guide published by the Chartered Association of Business Schools, a comprehensive ranking scheme that includes 1,582 journals [1]. We did this mainly to increase the likelihood of more theoretical discussions of these concepts as usually required in higher ranked journals. This step left us with our final sample of 130 papers [2].

As can be seen in Figure 1, the first publications date back to 2008. After a period of six years, the publications started to increase significantly between 2014 and 2016, interrupted by a pullback in the years 2017 and 2018. Since then, publications on these topics re-emerged with 22 publications in 2019 and peaked with 35 in 2020 (to date).

Note that, prior to this special issue, very few publications have been published in top tier (ABS4 and $4 *$ ) OSCM journals, as well as adjacent fields, such as general management, strategic management, ethics/corporate governance and accounting (Table 1). The vast majority of papers have been published in Journal of Cleaner Production (50; ABS2), followed by International Journal of Production Economics (14; ABS3) and International Journal of Operations and Production Management (ABS4), four of which were published prior to this special issue.

However, after a more detailed analysis of the sample papers, it became clear that a wide range of papers mainly discuss the term "trade-off", but less so "tension" and very rarely "(un) anticipated outcomes" (Table 2). 
IJOPM

40,12

1754

Figure 1.

Published papers per year

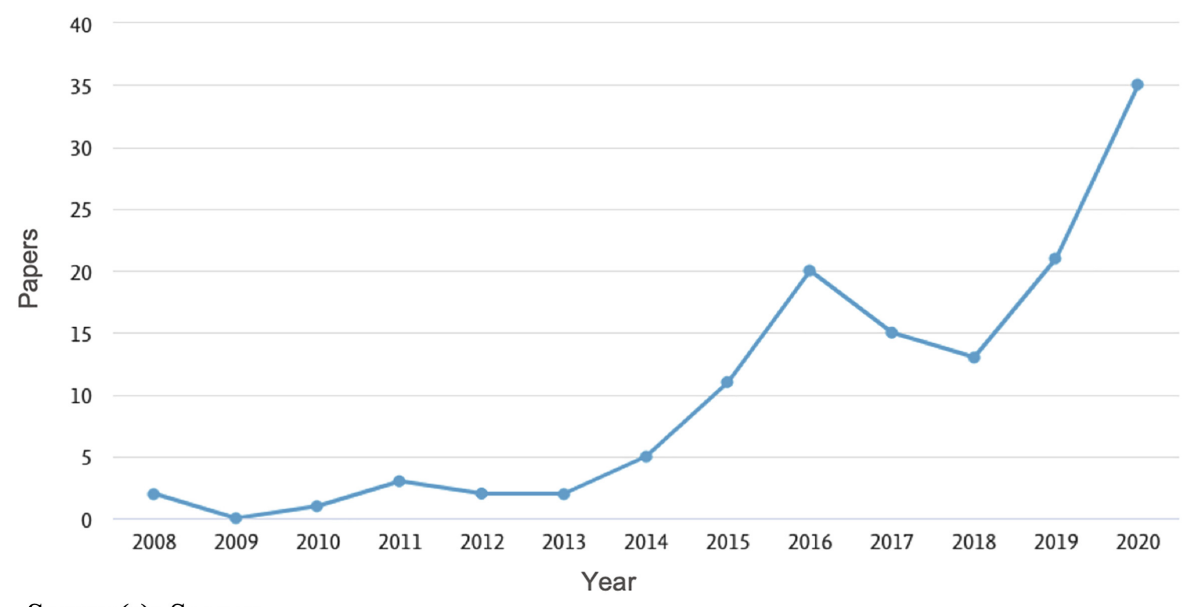

Source(s): Scopus

\begin{tabular}{|c|c|c|}
\hline Journal & \# of publications & ABS journal ranking 2018 \\
\hline Academy of Management Journal & 1 & $\mathrm{ABS} 4^{*}$ \\
\hline Journal of Operations Management & 1 & $\mathrm{ABS} 4 *$ \\
\hline Int. Journal of Operations and Production Management & $10^{\dagger}$ & ABS 4 \\
\hline Production and Operations Management & 3 & ABS 4 \\
\hline Int. Journal of Production Economics & 14 & ABS 3 \\
\hline Int. Journal of Production Research & 7 & ABS 3 \\
\hline Business Strategy and the Environment & 6 & ABS 3 \\
\hline Production Planning and Control & 6 & ABS 3 \\
\hline Transportation Research Part E & 4 & ABS 3 \\
\hline Journal of Supply Chain Management & 4 & ABS 3 \\
\hline Journal of Business Ethics & 3 & ABS 3 \\
\hline Supply Chain Management & 2 & ABS 3 \\
\hline Omega & 2 & ABS 3 \\
\hline Accounting, Auditing and Accountability & 1 & ABS 3 \\
\hline California Management Review & 1 & ABS 3 \\
\hline Corporate Governance & 1 & ABS 3 \\
\hline Decision Support Systems & 1 & ABS 3 \\
\hline Organization & 1 & ABS 3 \\
\hline Journal of Cleaner Production & 50 & ABS 2 \\
\hline Int. Journal of Phys. Distr. \& Logistics Management & 4 & ABS 2 \\
\hline Journal of Business Logistics & 2 & ABS 2 \\
\hline Sustainability Accounting, Management and Policy & 2 & ABS 2 \\
\hline Journal of Service Management & 1 & ABS 2 \\
\hline Journal of Social Entrepreneurship & 1 & ABS 2 \\
\hline Journal of Strategic Marketing & 1 & ABS 2 \\
\hline Organization and Environment & 1 & ABS 2 \\
\hline
\end{tabular}

Table 1.

Published papers per ranked journal
Sustainability trade-offs

In general, trade-offs can be defined as situations in which one or more sustainability element(s) is/are chosen over one or more other sustainability elements at their expense (Fracarolli Nunes et al., 2020). Trade-off and win-win studies often follow an instrumental 
logic with the aim of stricter alignment between different dimensions or goals (Tuni et al., 2020). Consequently, many studies typically investigate trade-offs within a single sustainability dimension, such as the trade-off between land use and $\mathrm{CO}_{2}$ emissions (Niu et al., 2020); between two different sustainability dimensions, such as financial vs environmental objectives (e.g. Darvish et al., 2019; Eskandarpour et al., 2019; Saunders et al., 2020) or social and environmental aspects (Galeazzo and Klassen, 2015); between other key OSCM concepts such as supply chain resilience and supply chain sustainability (e.g. Ivanov, 2018; Fahimnia et al., 2018), lean and green supply chains (Baumer-Cardoso et al., 2020) or quality and environmental concerns (Li, 2013); or among all conflicting economic, environmental and social objectives altogether (e.g. Rabbani et al., 2018; Martins et al., 2019).

While these research streams have merit for the OSCM field, we rarely found the trade-off concept being further conceptualized or sources for these trade-offs to be examined within these publications, with notable exemptions (e.g. Dabhilkar et al., 2016; Rodríguez et al., 2016; Brennan and Tennant, 2018; Koster et al., 2019; Longoni et al., 2019). In this light, the aim of this special issue is to foster research that more actively engages with the challenges of unanticipated outcomes, tensions and trade-offs from a conceptual stance.

\section{Sustainability tensions}

Tensions may be conceived as the relationship between the two poles of a paradox, which appear incompatible and/or illogical when taken together (Wannags and Gold, 2020). Research under the term "tension" is usually quite heterogenous, and the concept is sometimes used as an umbrella for win-win, trade-off, integrative and paradox sustainability research (Van der Byl and Slawinski, 2015). This seems to be the reason why we have found the tension discourses more conceptually coined and explorative than the mere focus on trade-offs.

Examples of sustainability tensions research include Ndubisi et al. (2020), who studies conflicting stakeholder demands and various management mechanisms as sources for tensions in the context of closed-loop technology and blood metals. Focusing on multistakeholder initiatives, Boersma (2018) identifies tensions between the normativeethical and political-strategic dimensions within these entities as well as tensions regarding the effectiveness of supply chain auditing, broadening labor rights to remediate child labor and the role of standards. Meqdadi et al. (2020) examine the potential tensions between social and commercial logics in social enterprises, finding that mitigation can be achieved through monitoring and development of individual relationships and through the structure of the network (e.g. NGOs and direct suppliers). In their study on CSR integration within a construction company's business strategy, Siltaloppi et al. (2020) find three types of tensions: (1) those between past understandings and future visions; (2) between competing decisionmaking rationales and (3) the tension of inconsistent behaviors.

Xiao et al. (2019) apply a paradox perspective on tensions in sustainable supply chain management within an emerging market context. They highlight that tensions are not problematic per se, but may become so depending on buyers' and suppliers' responses to them, where sustainability manager's contextualizing can alleviate such tensions (Xiao et al., 2019). Consistent with previous research (Busse et al., 2016), Golicic et al. (2020) underline the complexity and ambiguity of social sustainability and call for a common global and

\begin{tabular}{lc}
\hline Keyword & \# Of publications \\
\hline Trade-off & 103 \\
Tension & 21 \\
Unintended & 10 \\
Unanticipated & 2
\end{tabular}

Table 2.

Appearance of keywords among 130 papers 
IJOPM

40,12

contextual definition of this concept. From a procurement perspective, Fayezi et al. (2018) illustrate procurement sustainability tensions on the company and supply chain level and provide an analysis of the manifestation of these tensions. More specifically, they identify different legitimacy contexts (temporal and spatial) surrounding the procurement function, and analyze the impact of institutional distance between these contexts of procurement and their salient stakeholders as sources for these tensions.

\section{Unanticipated outcomes in the quest for sustainability}

The vast majority of unanticipated outcomes identified in the literature relate to social and environmental issues. For example, Tencati et al. (2008) were among the first to shed light on unanticipated outcomes from CSR in their study on Vietnamese suppliers in global supply chains. They emphasize that bluntly imposing CSR on suppliers might have the adverse effect of triggering protectionism. CSR by Western companies should therefore be pursued through innovative partnerships and a demand-driven educational agenda. Arya and Mittendorf (2015) examine the wider consequences for supply chains when CSR subsidies are offered. They found that while encouraging socially beneficial CSR behavior, subsidies can also harm consumers in primary markets by inflating prices. Ugarte et al. (2016) found that while some lean logistics practices improve operational performance, they may unintentionally increase environmental impacts. The study by Tan et al. (2017) in China found that enforcing environmental regulations often exacerbated opportunistic behavior at the expense of other stakeholders. The study by Naumov et al. (2020) on automated vehicles found that carpooling initiatives could actually unintentionally result in making traffic congestion worse. Zarei et al. (2019) found that even humanitarian supply chains have unintended consequences, where for example detrimental environmental outcomes are often neglected.

Crop certification schemes have been regarded as a mechanism to ensure supply chain sustainability through for example increased small farmer technology adoption and improved market knowledge, resulting in higher and more reliable income for those able to comply (Scarlat and Dallemand, 2011). However, certification has also been known to cause a number of adverse unexpected effects including local food security issues, loss of land ownership and gender inequality (Oosterveer et al., 2014; Schleifer and Sun, 2020).

By investigating tensions on individual, organizational and supply chain levels, Gruchmann et al. (2020) were able to explain why automation and ergonomic practices in warehouse logistics are not adequately implemented, despite health, safety and operational performance benefits. They found that tensions are primarily caused by increased cognitive requirements for these workplace innovations versus supply chain customer pressures based on price and flexibility. From an accounting perspective on supply chains, Gold and Heikkurinen (2018) argue that stakeholder calls for greater supply chain transparency do not lead to increased corporate responsibility and accountability, since they tend to spur corporate narratives of self-praise rather than increase supply chain sustainability. Such action would need to acknowledge and embrace the existence of organizational opaqueness and deal with the complexity, distance and resistance within international supply chains.

Within an emerging economy context, Esfahbodi et al. (2016) found a time dependence regarding the trade-off between the adoption of SSCM practices and improved cost performance. They explain that such tension can be minimized if firms take a long-term view on profit gains. Although the influence of poverty common within developing countries are often the focus of studies in crop certification, a recent review of the literature concluded that there is limited evidence linking certification and social-economic outcomes, and as a result they remain insufficiently understood (Schleifer and Sun, 2020). A key reason is attributed to the high dependence of local data on certification impact.

The next section outlines the papers included in this special issue, and specifically how they address some of the deficiencies outlined in this section. 
Overview of papers in this special issue

This special issue brought together research on the underlying processes by which unanticipated outcomes, either positive or negative, may result from attempts at developing more sustainable OSCM. The selected papers illuminate how good intentions result in unanticipated outcomes, which may emerge through unexpected or hidden connections between stakeholders and issues at stake.

Drawing on an ethnographic study, Glover (2020) discusses supply chain relationship dynamics between supermarkets and farmers and illustrate that sustainability initiatives often favor one partner at the expense of another. SSCM may thus lead to negative unintended consequences, such as impacts on farmers' well-being and increased stress levels in the working environment. In contrast, supermarkets benefit from such initiatives as they help to consolidate their power over suppliers while improving environmental performance. The intriguing point here is whether such a negative outcome was in fact "unintended". As discussed above, decisions may be performed without awareness, and it is not always possible to presume that decisions involve a clear-cut purpose, or whether the actor refused to consider additional aspects to favor a particular interest or value. The study by Glover (2020) thus opens interesting venues for ethnographic research in SCM, the mechanisms involved in the decision to adopt sustainable SCM, and the integration of communities in which the supply chains operate.

The study developed by Ye et al. (2020) challenges the traditional assumption that certification processes assures better operations management performance. They examine whether good intentions, such as the adoption of ISO 14001, an international environmental management accreditation, help firms gain a win-win paradigm regarding environmental process improvement and a competitive advantage in the market. The results indicate that although ISO 14001 leads to lower financial risk, it may hinder sales growth, an unanticipated outcome. The latter is caused by the lock-in effect that ISO standards may exert on firms' practices, leading to a risk-aversive mind-set and by the high costs of accreditation processes, hindering deployable resources for market expansion. This unanticipated trade-off worsens over time, becoming particularly more severe among firms that adopt ISO 14001 early and operate in less-polluting industries. They thus suggest these mixed aspects of certification highlight the influence of timing and industrial contexts and recommend the wise use of such standard instruments.

Based on interviews with managers and owners of apparel subsuppliers and with institutional actors in Bangladesh, Nath et al. (2020) examine how developing country subsuppliers decouple the implementation of sustainable supply management practices through hybrid approaches involving both consensual and concealment strategies. Following a consensual strategy, subsuppliers communicate openly about their realities with institutional actors (e.g. buyers and first-tier suppliers) whom they trust; they agree mutually to not (fully) implement the sustainability standards. In contrast, concealment strategy means that subsuppliers hide noncompliant and/or unethical supply chain practices from institutional actors. The study finds that different conflicting institutional logics (i.e. instrumental logic, legitimacy logic complexity and gaps in normative logic) allow subsuppliers to decouple the implementation of sustainable practices. Nath et al. (2020) respond to the call for more empirical research on subsuppliers in a challenging developing country context, and refine our theoretical insights into subsuppliers' decoupling strategies as well as the underlying institutional frictions that facilitate these strategies.

Drawing on the institutional theory, business corruption and the sustainability standards literature, Silvestre et al. (2020) propose a typology of supply chain corruption practices. They suggest that if sustainable SCM practices are adopted symbolically and not substantively, unanticipated outcomes such as supply chain corruption may occur. They highlight that current economic/financial sustainability standards may lead to "social isomorphism for
Hidden side of sustainable OSCM 
IJOPM

40,12

corruption", enabled by low normative pressures (e.g. "nothing will happen if I do it"), high mimetic pressures (e.g. "everyone does it") and high coercive pressures (e.g. "if I don't do it, I will be excluded"). They conclude that corruption practices can be prevented if focal companies promote substantive, as opposed to symbolic, adoption of sustainability standards across their supply chains.

Carter et al. (2020) develop a typology of the unintended consequences of sustainable SCM initiatives and propose a conceptual model of the antecedents of these unintended consequences. The authors draw on paradox theory to identify multiple levels of stakeholders, performance dimensions, time horizons and the interplay with social construction as key antecedents of unintended consequences of sustainable SCM. They found that such antecedents demonstrate the need to focus research on interactions within and between social and environmental performance. In doing so, they contribute to the theorization, i.e. the why and the how, of unintended consequences within sustainable SCM. They also highlight that the resultant unintended consequences can provide an initial invaluable roadmap for managers to continue, discontinue or further consider a SSCM initiative.

The study by Wontner et al. (2020) explores the challenges of implementing a sustainable public procurement policy in the form of community benefits to ensure that public expenditures result in positive social and economic outcomes for the local community. Drawing on resource dependence theory, they found that while implementing community benefit policies improve economic and social outcomes, differing views between buyers and suppliers often creates tensions, while unintended consequences may result when one form of community benefits (CB) is promoted over another. They advance resource dependency theory by developing four constructs: powerful stakeholders; intra- and interorganizational issues; challenges and enablers, to better understand power and resource flows for more sustainable public procurement.

Table 3 provides an exemplary summary of sustainable OSCM literature on trade-offs, tensions and unanticipated outcomes. In the next section, we draw on these studies, as well as the sociology and behavioral science literatures to propose a model that paves the way of possible antecedents of (un)anticipated consequences in OSCM.

\section{A model of the antecedents of (un)anticipated consequences in sustainable OSCM}

A key issue related to the anticipation of consequence, is the state of knowledge in which actions are taken and analyses are made. In this section, we develop a model that explains four possible mechanisms through which different states of knowledge may lead to (un) anticipated outcomes (Figure 2).

Merton (1936) suggests that unanticipated outcomes may emerge due to ignorance, error or immediacy of interest, i.e. when the actor's preoccupation with the foreseen short-term consequences hinders consideration of long-term ones (Quadrant-I). Ignorance has been a common factor for explaining unanticipated outcomes and relates to limitations in foreseeing events related to novel and complex situations. Such situations could arise with the emergence of new technologies for which the impacts, particularly long-term ones, are largely unknown. Studies on artificial intelligence (AI) technologies in medical applications for example found that while some outcomes such as the loss of social rituals between patient and doctor could be anticipated, others such as how women and racial minorities were treated were missed (Hashimoto et al., 2018; Verghese et al., 2018). In the supply chain field, limited available information on relevant suppliers required regulatory frameworks or consumer acceptance, hindering the development of accurate consequence analysis (Matos and Hall, 2007). 
Trade-offs between

Land use vs $\mathrm{CO}_{2}$ emissions reduction

Financial vs environmental objectives

Social vs environmental objectives

Supply chain resilience vs sustainability

Lean vs green supply chain

Economic vs environmental vs social objectives altogether

Product quality vs environmental concerns

\section{Tensions between}

Stakeholder demands and various management mechanisms Normative-ethical and political-strategic dimensions Supply chain auditing effectiveness and labor rights

Social and commercial logics in social enterprises

Past understandings and future visions

Competing decision-making rationales Inconsistent behaviors in strategy

Procurement sustainability tensions

Buyers' and suppliers' responses to tensions

Innovations' cognitive requirements and price and flexibility pressures

Unanticipated outcomes in the quest for sustainability

Supply chain protectionism

Price inflation

Unintentional environmental impacts

Opportunistic behavior

Food security issues, loss of land ownership and gender inequality

Corporate narratives of self-praise and/or exculpation

Coercion and corruption

Environmental standards adoption hindering sales growth Impact of social well-being of suppliers
Niu et al. (2020)

Darvish et al. (2019); Eskandarpour et al.

(2019), Saunders et al. (2020)

Galeazzo and Klassen (2015)

Ivanov (2018), Fahimnia et al. (2018)

Baumer-Cardoso et al. (2020)

Rabbani et al. (2018), Martins et al. (2019)

Li (2013)

Ndubisi et al. (2020)

Boersma (2018)

Meqdadi et al. (2020)

Siltaloppi et al. (2020)

Fayezi et al. (2018), Wontner et al. (2020)

Xiao et al. (2019)

Gruchmann et al. (2020)

Tencati et al. (2008)

Arya and Mittendorf (2015)

Ugarte et al. (2016), Zarei et al. (2019),

Naumov et al. (2020)

Tan et al. (2017), Wontner et al. (2020)

Oosterveer et al. (2014), Schleifer and Sun (2020)

Gold and Heikkurinen (2018)

Silvestre et al. (2020)

Ye et al. (2020)

Glover (2020)
Table 3.

Examples of trade-offs, tensions and unanticipated outcomes from the literature

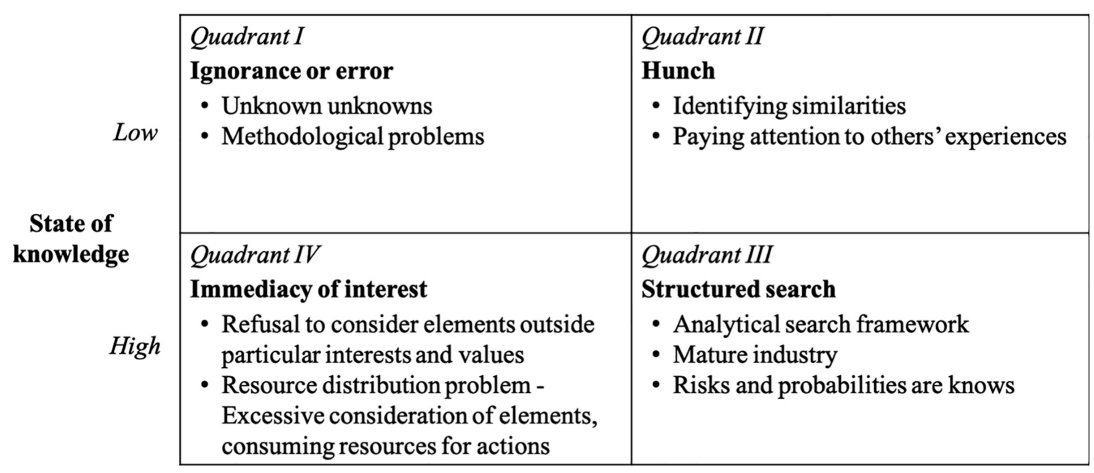

Unanticipated
Figure 2.

State of knowledge and (un)anticipated consequences 
IJOPM

40,12

Another major factor leading to unintended consequences is error, which Merton (1936) suggests arise from inappropriate assessment of the current situation, which in turn compromises appropriate selection and execution of action. Weak assessment of sustainability issues may be due to poor methodological approaches in identifying, collecting and analyzing relevant data, a problem that has been discussed in the OSCM literature (e.g. Lambert and Enz, 2017; Towers et al., 2020). Criminal practices around supply chain management, such as modern slavery (Gold et al., 2015; Benstead et al., 2018), corruption (Silvestre et al., 2020, this issue) or conflict minerals (Hofmann et al., 2018) also pose strong challenges to the reliability and validity of data.

Of particular concern here is the difficulty in dealing with the complications of sustainability in supply chains. Given that sustainability involves a large number of social, environmental and economic factors (Varsei et al., 2014), one problem is how many variables need to be taken into consideration to allow for the development of a robust study. This involves the difficult choice and justification of defining the study's scope, which for example could attempt to include all social, environmental and economic issues versus focusing on only some, determining the number of tiers within the supply chain that will be considered, and identifying which stakeholders are relevant. For example, some studies have focused supply chain analysis toward vertical multi-tier supply chain management (e.g. Tachizawa and Wong, 2014; Carter et al., 2015; Meinlschmidt et al., 2018; Villena, 2019), thereby neglecting potentially vast horizontal complexities that may arise on single supply chain tiers through the practice of (unauthorized) subcontracting (Caro et al., 2020; Gold et al., 2020). The study in this issue by Nath et al. (2020) shows an example of how unanticipated consequences can be identified by horizontally examining subsupplier relations.

In addition to the challenges in defining the right scope of analysis, a second and related difficulty is to ensure that the consequences are being attributed to the right actions, i.e. avoiding casual imputation (Saleh, 2009). Sustainability issues, with systemically intertwined social-economic and technical factors (cf. Kull et al., 2013), thus call for holistic methodological approaches that include both inductive and deductive methods that complement each other (Eisenhardt et al., 2016) as well as complementary modeling and simulation techniques. For example, while deductive approaches (often based on regression-based econometrics) can effectively identify what unanticipated outcomes are, inductive methods (often based on qualitative methods) can uncover the reasons why such consequences emerged, enabling actors to discern and perhaps take control of a relevant issue. The paper by Glover (2020) for example, used ethnographic observations to reveal why the implementation of sustainable SCM in the dairy industry may have negative effects. Modeling and simulation techniques based on empirical data, such as system dynamics or agent-based modeling, may help complementing findings from qualitative and quantitative empirical research through a distinct systems perspective that acknowledges for example a wide range of actors, temporal dynamics or nonlinear relationships between variables. Modeling techniques may thus facilitate refuting, corroborating, or refining findings or theory from empirical research through methodological triangulation (Gold et al., 2020).

Simon (1962) defined limitations in knowledge that are imposed by complexity as bounded rationality, and as a result, decisions are often made, according to Knight (1921), on the bases of opinion and estimate instead of scientific knowledge (Quadrant-II). Thus, under limited access to information that restricts calculations or other possible ways of deduction, decisions may be made on the bases of "hunches" Merton (1936). This can involve, for example, analogical reasoning where in the absence of better data and adequate analytical tools, managers transfer previous knowledge from similar industry or other relevant characteristics to guide their decisions in the novel situation (Gavetti et al., 2005). Such a "hunch" will then depend on managers' personal experiences or capability of identifying 
similarities from paying attention to the experience of others. For example, the delays and controversy during the implementation of transgenic technology over the last 20 years, have provided clear evidence of the importance of considering consumer acceptance and supply chain integration issues during early stages of technology development in the agro-biotech industry (Hall et al., 2014). Modeling techniques may help managers and other decisionmakers to find a satisficing strategy right from the beginning, as it allows sensitivity analysis and "trial and error" within the model and thus prevents (time-consuming and costly) "trial and error" in the real world.

A contrasting and more favorable scenario, is the careful consideration for all pitfalls and challenges discussed above by adopting a "structured search approach" (Quadrant-III), which features known scopes of data collection and analysis, leading to high knowledge levels and thus a satisfactory anticipation of consequences. Previous studies have applied the complex adaptive systems paradigm to OSCM that considers complexity between agents, environments and emergent system properties spanning both micro- and macro levels (e.g. Koh et al., 2017; Nair and Reed-Tsochas, 2019). Others have applied Simon's (1962) concept of complexity theory in supply chains (e.g. Choi et al., 2001) and sustainability management (e.g. Matos and Hall, 2007). The latter study proposes an analytical framework to help practitioners to identify both obvious and not-so-obvious interactions, where parameters and uncertainties are identified and assessed by searching for interdependences, essentially turning uncertainties into probabilistic risks. Once this is achieved, satisfactory solutions can be identified. In this special issue, Ye et al. (2020) show that a proper analysis can reveal negative outcomes of practices usually assumed to bring positive sustainability outcomes, such as an organization's certification with ISO 14001. Also in this special issue, Wontner et al. (2020) suggest that ensuring supplier-buyer communication at early contract stages increases coordination, which avoids unanticipated consequences of sustainable public procurement policies.

Another possible scenario of high state of knowledge leading to anticipated outcomes may include gambling, where risks and probabilities are known, as well as mature industry sectors such as oil and gas, with well-established science, supply chain infrastructure and knowledge about its environmental impact. The recent example of COVID-19 has shown that these states of high knowledge regarding scope of data search and analysis are still islands in a sea of uncertainty that can be quickly flooded by unforeseen events that require adaptations toward a not (yet) known new state of "normal".

High knowledge can also lead to unanticipated consequences when, for example, an actor purposively refuses to consider certain elements but instead focuses on a particular interest or value, i.e. Merton's immediacy of interest (Quadrant-IV). These are cases of "stakeholder ambiguity", a term coined by Hall and Vredenburg (2003), where it is difficult to identify the elements at stake and/or why stakeholders may oppose them. As a result, decision-making heuristics based on scientific evidence thus might not work. For example, in this special issue, Silvestre et al. (2020) show that some sustainable SCM practices may have a hidden and symbolic rather than an explicit and sustainability improvement intent. Anticipated outcomes, however, may seem positive and desirable to certain actors, although they may seem negative to others. According to Merton (1936), such controversy is true even in situations where the intended result is "the lesser of two evils" (p. 895). For example, one may argue that in the case of sustainable SCM, improving at least one of the environmental or the social dimensions of sustainability is better than if neither were attempted. Lastly, a high state of knowledge may also result in unanticipated outcomes when too much effort and resources are devoted to collect information, increasing the level of complexity to such high levels that little time and energy is left to reach a conclusion. This may be due to a preoccupation with implementing an activity (i.e. "ticking all the right boxes"), rather than focusing on the actual benefits that the initiative may bring. 
IJOPM

40,12

1762

As per their nature, trade-offs have to remain below optimal solutions, leaving a wide spectrum for tensions and unanticipated/unintended consequences and effects of managerial decision-making and policy implementation. More specifically, it means that both theory and practice should acknowledge that the a priori postulated link between addressing sustainable OSCM concerns and an overall positive societal and environmental (let alone economic) contribution might be decoupled, or at least severely delayed. Furthermore, even when the decision of implementing sustainable OSCM is based on the best intentions, ultimately the consequences of such decision will depend on the interplay of a number of different variables and players, or as referred by Knight (1921), the conditions of action under uncertainty. Consequently, much more attention in OSCM research needs to focus on the unintended consequences of good intentions toward sustainable OSCM.

While this special issue attempted to address some of the concerns outlined in this paper, there are still a number of areas of investigation that warrant attention, as summarized in Table 4. This includes some suggestions on how methodological approaches can be

\begin{tabular}{ll}
\hline Research category & Specific areas for future research \\
\hline
\end{tabular}

Methodological issues

Contextual factors

Contemporary examples that may trigger unanticipated outcomes
(1) Need to consider greater complexity, especially with not-soobvious interactions among actor groups, and/or among economic, environmental and social parameters

(2) Need for better triangulation/data verification, control over social desirability bias and attention to causal imputation

(3) For relatively short-term trade-offs and tensions, there are established methods (e.g. inductive research, system dynamics, agent-based modeling, etc.), which can be applied within a sustainability context

(4) For longer term unanticipated outcomes, there are relatively less established methods within OSCM literature, calling for the development of novel methods that build on longitudinal and/or ethnographic studies, sustainability transitions approaches, etc.

(1) Emerging vs developed countries

(2) Varying sustainability capabilities among organizations

(3) Horizontal complexity on each supply chain stage

(4) Supply chain position

(5) Conflicting stakeholder demands (ambiguity)

(6) Regulatory factors, governance structures and institutional environments

(7) Organizational and decision processes

(8) Individual behavior

(1) Pandemics and other global disasters that challenge the resilience of highly efficient but perhaps vulnerable lean supply chains, power balances and national and regional economic stability

(2) The impact of climate change and sustainability risks, and how they may impact logistics, international supply chains, fair trade, social inclusion, etc.

(3) Geo-political shifts that may foster or hinder globalization and trade (e.g. Trumpism vs Bidenism, US-Chinese trade war, Brexit, etc.)

(4) The impact of emerging technologies and OSCM concepts, such as reverse logistics, resilience, sustainability decision processes, Industry 4.0, digitalization, artificial intelligence, blockchain and other distributed ledger technologies, smart contracting, 3D printing, etc.
Table 4.

Future research directions 
improved, as well as contextual factors that shape (or are shaped) by some contemporary examples that may trigger unanticipated outcomes. For example, research is needed on OSCM issues related to unanticipated outcomes and potential ripple effects of technological innovation. Another underexplored issue is the displacement of harmful activities from one organization only to be adopted by another, which may have lower sustainability capabilities or operate under governance structures with weaker institutions. In addition, the recent COVID-19 pandemic has raised significant supply chain issues that need to be examined. For example, what issues have been exposed by the pandemic on the (un)sustainable side effects of popular OSCM concepts, such as reverse logistics, just-in-time and lean manufacturing? Did sustainable OSCM initiatives get thrown out to make room for other priorities?

On a more positive note, we also need to consider approaches that improve various sustainability goals, perhaps in other sectors, industrial applications and/or markets that exceed what was originally intended. This also includes findings on intangible by-products, such as knowledge accumulation from learning, resilience and self-organizing experiences that can have a positive impact toward sustainable OSCM.

\section{Conclusion}

The purpose of this paper and special issue was to explore the (un)anticipated outcomes, trade-offs and tensions in sustainable OSCM in an attempt to improve our capabilities to transition toward more sustainable practices and societies. In general, the literature suggests that trade-offs and tensions tend to focus on economic criteria, rather than sustainability concerns, whereas the much less researched area of unanticipated consequences often relate to unforeseen negative social and environmental factors. Thus, although scholars have known for some time that attempts to improve specific supply chain parameters will impact others, much less attention has been focused on how this affects sustainable OSCM. Rather than treating (un)anticipated outcomes, trade-offs and tensions as aberrations or exceptions, they should be seen as inevitable, and thus managed.

Although coming from different directions, the empirical and theoretical work of the selected papers for this special issue point out that unintended outcomes may arise when relevant interactions are disregarded. Overall, these studies indicate the reasons why they may vary between ignorance and self-interest (Nath et al., 2020; Silvestre et al., 2020; Glover, 2020) or, due to complexity, these interactions may be difficult to identify (Carter et al., 2020; Wontner et al., 2020; Ye et al., 2020). While these studies significantly contribute to describing the phenomena of trade-offs and unintended issues, it is still not clear how such problems emerge. The model developed in this paper aimed at paving the way to address this gap by highlighting the crucial effect of the underlying state of knowledge on sustainable OSCM decision-making.

\section{Notes}

1. https://charteredabs.org/academic-journal-guide-2018/

2. A full list of these papers is available from the authors upon request.

\section{References}

AFP (Agence France-Presse) (2020), "South African rhino poaching halves in six months thanks to Covid-19 lockdown", The Guardian, (1 August 2020), available at: www.theguardian.com/ environment/2020/aug/01/south-african-rhino-poaching-halves-in-six-months-thanks-to-covid19-lockdown (accessed 12 October 2020). 
IJOPM

40,12
Arya, A. and Mittendorf, B. (2015), "Supply chain consequences of subsidies for corporate social responsibility”, Production and Operations Management, Vol. 24 No. 8, pp. 1346-1357.

Ash, J.S., Berg, M. and Coiera, E. (2004), "Some unintended consequences of information technology in health care: the nature of patient care information system-related errors", Journal of the American Medical Informatics Association, Vol. 11 No. 2, pp. 104-112.

Baumer-Cardoso, M.I., Campos, L.M.S., Portela Santos, P.P. and Frazzon, E.M. (2020), "Simulationbased analysis of catalyzers and trade-offs in Lean and Green manufacturing", Journal of Cleaner Production, Vol. 242, p. 118411.

Benstead, A.V., Hendry, L.C. and Stevenson, M. (2018), "Horizontal collaboration in response to modern slavery legislation: an action research project", International Journal of Operations and Production Management, Vol. 38 No. 12, pp. 2286-2312.

Boersma, M. (2018), "Between norms and practice: civil society perspectives on the legitimacy of multistakeholder initiatives to eliminate child labor", Business Strategy and the Environment, Vol. 27 No. 5, pp. 612-620.

Brennan, G. and Tennant, M. (2018), "Sustainable value and trade-offs: exploring situational logics and power relations in a UK brewery's malt supply network business model", Business Strategy and the Environment, Vol. 27 No. 5, pp. 621-630.

Busse, C., Schleper, M.C., Niu, M. and Wagner, S.M. (2016), "Supplier development for sustainability: contextual barriers in global supply chains", International Journal of Physical Distribution and Logistics Management, Vol. 46 No. 5, pp. 442-468.

Caro, F., Lane, L. and Saez de Tejada Cuenca, A. (2020), "Can brands claim ignorance? Unauthorized subcontracting in apparel supply chains”, Management Science, Vol. ahead-of-print No. aheadof-print. doi: 10.1287/mnsc.2020.3679.

Carter, C.R., Rogers, D.S. and Choi, T.Y. (2015), "Toward the theory of the supply chain”, Journal of Supply Chain Management, Vol. 51 No. 2, pp. 89-97.

Carter, C.R., Kaufmann, L. and Ketchen, D.J. (2020), "Expect the unexpected: toward a theory of the unintended consequences of sustainable supply chain management", International Journal of Operations \& Production Management, Vol. ahead-of-print No. ahead-of-print. doi: 10.1108/ IJOPM-05-2020-0326.

Carnovale, W. Jr, Henke, S.J., DuHadway, S. and Yeniyurt, S. (2019), "Unintended consequences: how suppliers compensate for price concessions and the role of organizational justice in buyersupplier relations", Journal of Business Logistics, Vol. 40 No. 3, pp. 187-203.

Choi, K. (2018), "A system perspective on revenue sharing in the mobile value chain: an evidence from China mobile video ecosystem”, Supply Chain Management, Vol. 12 No. 3, pp. 136-152.

Choi, T.Y., Dooley, K.J. and Rungtusanatham, M. (2001), "Supply networks and complex adaptive systems: control versus emergence”, Journal of Operations Management, Vol. 19, pp. 351-366.

Cousins, P.D., Lawson, B., Petersen, K.J. and Fugate, B. (2019), "Investigating green supply chain management practices and performance: the moderating roles of supply chain ecocentricity and traceability", International Journal of Operations and Production Management, Vol. 39 No. 5, pp. 767-786.

Dabhilkar, M., Bengtsson, L. and Lakemond, N. (2016), "Sustainable supply management as a purchasing capability - a power and dependence perspective", International Journal of Operations and Production Management, Vol. 36 No. 1, pp. 2-22.

Darvish, M., Archetti, C. and Coelho, L.C. (2019), "Trade-offs between environmental and economic performance in production and inventory-routing problems", International Journal of Production Economics, Vol. 217 No. C, pp. 269-280.

Eisenhardt, K.M., Graebner, M.E. and Sonenshein, S. (2016), "Grand challenges and inductive methods: rigor without rigor mortis”, Academy of Management Journal, Vol. 59 No. 4, pp. 1113-1123. 
Emiliani, M.L., Stec, D.J. and Grasso, L.P. (2005), "Unintended responses to a traditional purchasing performance metric", Supply Chain Management, Vol. 10 No. 3, pp. 150-156.

Esfahbodi, A., Zhang, Y. and Watson, G. (2016), "Sustainable supply chain management in emerging economies: trade-offs between environmental and cost performance", International Journal of Production Economics, Vol. 181, pp. 350-366.

Eskandarpour, M., Dejax, P. and Péton, O. (2019), "Multi-directional local search for sustainable supply chain network design", International Journal of Production Research, Vol. ahead-of-print No. ahead-of-print. doi: 10.1080/00207543.2019.1696488.

Evenson, R.E. and Gollin, D. (2003), "Assessing the impact of the green revolution, 1960 to 2000", Science, Vol. 300 No. 5620, pp. 758-762.

Fahimnia, B. and Jabbarzadeh, A. (2016), "Marrying supply chain sustainability and resilience: a match made in heaven", Transportation Research Part E: Logistics and Transportation Review, Vol. 91, pp. 306-324.

Fahimnia, B., Jabbarzadeh, A. and Sarkis, J. (2018), "Greening versus resilience: a supply chain design perspective", Transportation Research Part E: Logistics and Transportation Review, Vol. 119, pp. 129-148.

Fayezi, S., Zomorrodi, M. and Bals, L. (2018), "Procurement sustainability tensions: an integrative perspective", International Journal of Physical Distribution and Logistics Management, Vol. 48 No. 6, pp. 586-609.

Ferdows, K. and De Meyer, A. (1990), "Lasting improvements in manufacturing performance: in search of a new theory", Journal of Operations Management, Vol. 9 No. 2, pp. 168-184.

Foerstl, K., Reuter, C., Hartmann, E. and Blome, C. (2010), "Managing supplier sustainability risks in a dynamically changing environment-sustainable supplier management in the chemical industry", Journal of Purchasing and Supply Management, Vol. 16 No. 2, pp. 118-130.

Fracarolli Nunes, M., Lee Park, C. and Paiva, E.L. (2020), "Can we have it all? Sustainability trade-offs and cross-insurance mechanisms in supply chains", International Journal of Operations \& Production Management, Vol. 40 No. 9, pp. 1339-1366.

Galeazzo, A. and Klassen, R.D. (2015), "Organizational context and the implementation of environmental and social practices: what are the linkages to manufacturing strategy?", Journal of Cleaner Production, (Part A), Vol. 108, pp. 158-168.

Gavetti, G., Levinthal, D.A. and Rivkin, J.W. (2005), "Strategy making in novel and complex worlds: the power of analogy”, Strategic Management Journal, Vol. 26 No. 8, pp. 691-712.

George, G., Howard-Grenville, J., Joshi, A. and Tihanyi, L. (2016), "Understanding and tackling societal grand challenges through management research”, Academy of Management Journal, Vol. 59 No. 6, pp. 1880-1895.

Giannakis, M. and Papadopoulos, T. (2016), "Supply chain sustainability: a risk management approach", International Journal of Production Economics, Vol. 171, pp. 455-470.

Glover, J. (2020), "The dark side of sustainable dairy supply chains", International Journal of Operations \& Production Management, Vol. ahead-of-print No. ahead-of-print. doi: 10.1108/ IJOPM-05-2019-0394.

Gold, S. and Heikkurinen, P. (2018), "Transparency fallacy: unintended consequences of stakeholder claims on responsibility in supply chains", Accounting, Auditing and Accountability Journal, Vol. 31 No. 1, pp. 318-337.

Gold, S. and Schleper, M.C. (2017), "A pathway towards true sustainability: a recognition foundation of sustainable supply chain management", European Management Journal, Vol. 35 No. 4, pp. 425-429.

Gold, S., Trautrims, A. and Trodd, Z. (2015), "Modern slavery challenges to supply chain management”, Supply Chain Management: An International Journal, Vol. 20 No. 5, pp. 485-494.

Gold, S., Chesney, T., Gruchmann, T. and Trautrims, A. (2020), "Diffusion of labor standards through supplier-subcontractor networks: an agent-based model", Journal of Industrial Ecology, Vol. 24 No. 6, pp. 1274-1286.
Hidden side of sustainable OSCM 
IJOPM

40,12

Golicic, S.L., Lenk, M.M. and Hazen, B.T. (2020), "A global meaning of supply chain social sustainability”, Production Planning and Control, Vol. 31 Nos 11-12, pp. 988-1004.

Gruchmann, T., Mies, A., Neukirchen, T. and Gold, S. (2020), "Tensions in sustainable warehousing: including the blue-collar perspective on automation and ergonomic workplace design", Journal of Business Economics, Vol. ahead-of-print No. ahead-of-print. doi: 10.1007/s11573-020-00991-1.

Guan, X. and Chen, Y.J. (2015), "Hierarchical quality disclosure in a supply chain with cost heterogeneity", Decision Support Systems, Vol. 76 No. C, pp. 63-75.

Haffar, M. and Searcy, C. (2017), "Classification of trade-offs encountered in the practice of corporate sustainability", Journal of Business Ethics, Vol. 140, pp. 495-522.

Hahn, T. and Knight, E. (2019), "The ontology of organizational paradox: a Quantum approach", Academy of Management Review, Vol. ahead-of-print No. ahead-of-print. doi: 10.5465/amr. 2018.0408 .

Hahn, T., Pinkse, J., Preuss, L. and Figge, F. (2015), "Tensions in corporate sustainability. Towards an integrative framework", Journal of Business Ethics, Vol. 127 No. 2, pp. 297-316.

Hajmohammad, S. and Shevchenko, A. (2020), "Mitigating sustainability risk in supplier populations: an agent-based simulation study", International Journal of Operations \& Production Management, Vol. 40 No. 7/8, pp. 897-920.

Hall, J. and Vredenburg, H. (2003), "The challenge of innovating for sustainable development", MIT Sloan Management Review, Vol. 45 No. 1, p. 61.

Hall, J., Matos, S. and Langford, C.H. (2008), "Social exclusion and transgenic technology: the case of Brazilian agriculture", Journal of Business Ethics, Vol. 77 No. 1, pp. 45-63.

Hall, J., Matos, S. and Silvestre, B. (2012), "Understanding why firms should invest in sustainable supply chains: a complexity approach", International Journal of Production Research, Vol. 50 No. 5, pp. 1332-1348.

Hall, J., Bachor, V. and Matos, S. (2014), "Developing and diffusing new technologies: strategies for legitimization”, California Management Review, Vol. 56 No. 3, pp. 98-117.

Hall, J., Matos, S., Gold, S. and Severino, L.S. (2018), "The paradox of sustainable innovation: the 'Eroom effect" (Moore's law backwards)", Journal of Cleaner Production, Vol. 172 No. 1, pp. 3487-3497.

Hallgren, M., Olhager, J. and Schroeder, R.G. (2011), "A hybrid model of competitive capabilities", International Journal of Operations and Production Management, Vol. 31 No. 5, pp. 511-526.

Hartmann, J. and Moeller, S. (2014), "Chain liability in multitier supply chains? Responsibility attributions for unsustainable supplier behavior", Journal of Operations Management, Vol. 32 No. 5, pp. 281-294.

Harvey, F. (2020), "Revealed: covid recovery plans threaten global climate hopes", The Guardian, available at: www.theguardian.com/environment/2020/nov/09/revealed-covid-recovery-plansthreaten-global-climate-hopes (accessed 9 November 2020).

Hashimoto, D.A., Rosman, G., Rus, D. and Meireles, O.R. (2018), “Artificial intelligence in surgery: promises and perils", Annals of Surgery, Vol. 268 No. 1, pp. 70-76.

Hofmann, H., Busse, C., Bode, C. and Henke, M. (2014), "Sustainability-related supply chain risks: conceptualization and management", Business Strategy and the Environment, Vol. 23 No. 3, pp. 160-172.

Hofmann, H., Schleper, M.C. and Blome, C. (2018), "Conflict minerals and supply chain due diligence: an exploratory study of multi-tier supply chains", Journal of Business Ethics, Vol. 147 No. 1, pp. $115-141$.

Ivanov, D. (2018), "Revealing interfaces of supply chain resilience and sustainability: a simulation study", International Journal of Production Research, Vol. 56 No. 10, pp. 3507-3523.

Jabbarzadeh, A., Fahimnia, B. and Sabouhi, F. (2018), "Resilient and sustainable supply chain design: sustainability analysis under disruption risks", International Journal of Production Research, Vol. 56 No. 17, pp. 5945-5968. 
Jonsson, P. and Holmström, J. (2016), "Future of supply chain planning: closing the gaps between practice and promise", International Journal of Physical Distribution and Logistics Management, Vol. 46 No. 1, pp. 62-81.

Knight, F.H. (1921), Risk, Uncertainty and Profit, Houghton Mifflin, New York and Boston, MA.

Hidden side of sustainable OSCM

Koh, S.C.L., Gunasekaran, A., Morris, J., Obayi, R. and Ebrahimi, S.M. (2017), "Conceptualizing a circular framework of supply chain resource sustainability", International Journal of Operations and Production Management, Vol. 37 No. 10, pp. 1520-1540.

Koster, M., Simaens, A. and Vos, B. (2019), "The Advocate's own challenges to behave in a sustainable way: an institutional analysis of advocacy NGOs", Journal of Business Ethics, Vol. 157 No. 2, pp. 483-501.

Kull, T.J., Ellis, S.C. and Narasimhan, R. (2013), "Reducing behavioral constraints to supplier integration: a socio-technical systems perspective", Journal of Supply Chain Management, Vol. 49 No. 1, pp. 64-86.

Lambert, D.M. and Enz, M.G. (2017), "Issues in supply chain management: progress and potential", Industrial Marketing Management, Vol. 62, pp. 1-16.

Le, T., Wang, Y., Liu, L., Yang, J., Yung, Y.L., Li, G. and Seinfeld, J.H. (2020), “Unexpected air pollution with marked emission reductions during the COVID-19 outbreak in China", Science, Vol. 369 No. 6504, pp. 702-706.

Lee, H.L., Padmanabhan, V. and Whang, S. (1997), "Information distortion in a supply chain: the bullwhip effect", Management Science, Vol. 43 No. 4, pp. 546-558.

Li, C. (2013), "An integrated approach to evaluating the production system in closed-loop supply chains", International Journal of Production Research, Vol. 51 No. 13, pp. 4045-4069.

Longoni, A., Pagell, M., Shevchenko, A. and Klassen, R. (2019), "Human capital routines and sustainability trade-offs: the influence of conflicting schemas for operations and safety managers", International Journal of Operations and Production Management, Vol. 39 No. 5, pp. 690-713.

Margolis, J.D. and Walsh, J.P. (2003), "Misery loves companies: rethinking social initiatives by business", Administrative Science Quarterly, Vol. 48 No. 2, pp. 268-305.

Maron, D.F. (2020), "Pandemic-induced poaching surges in Uganda", Nationalgeographic.com, available at: www.nationalgeographic.com/animals/2020/07/covid19-behind-uganda-poaching/ (accessed 12 October 2020).

Martins, C.L., Melo, M.T. and Pato, M.V. (2019), "Redesigning a food bank supply chain network in a triple bottom line context", International Journal of Production Economics, Vol. 214 No. C, pp. 234-247.

Matos, S. and Hall, J. (2007), "Integrating sustainable development in the supply chain: the case of life cycle assessment in oil and gas and agricultural biotechnology", Journal of Operations Management, Vol. 25 No. 6, p. 1083.

Merton, R.K. (1936), "The unanticipated consequences of purposive social action", American Sociological Review, Vol. 1 No. 6, pp. 894-904.

Meinlschmidt, J., Schleper, M.C. and Foerstl, K. (2018), "Tackling the sustainability iceberg: a transaction cost economics approach to lower tier sustainability management", International Journal of Operations and Production Management, Vol. 38 No. 10, pp. 1888-1914.

Mena, C. and Schoenherr, T. (2020), "The green contagion effect: an investigation into the propagation of environmental practices across multiple supply chains tiers", International Journal of Production Research, Vol. ahead-of-print No. ahead-of-print. doi: 10.1080/00207543.2020. 1834160.

Meqdadi, O., Johnsen, T.E. and Pagell, M. (2020), "Relationship configurations for procuring from social enterprises", International Journal of Operations and Production Management, Vol. 40 No. 6, pp. 819-845. 
IJOPM

40,12
Miemczyk, J. and Luzzini, D. (2019), “Achieving triple bottom line sustainability in supply chains: the role of environmental, social and risk assessment practices", International Journal of Operations and Production Management, Vol. 39 No. 2, pp. 238-259.

Nair, A. and Reed Tsochas, F. (2019), "Revisiting the complex adaptive systems paradigm: leading perspectives for researching operations and supply chain management issues", Journal of Operations Management, Vol. 65 No. 2, pp. 80-92.

Nath, S.D., Eweje, G. and Sajjad, A. (2020), "The hidden side of sub-supplier firms' sustainability - an empirical analysis", International Journal of Operations \& Production Management, Vol. aheadof-print No. ahead-of-print. doi: 10.1108/IJOPM-05-2019-0403.

Naumov, S., Keith, D.R. and Fine, C.H. (2020), "Unintended consequences of automated vehicles and pooling for urban transportation systems", Production and Operations Management, Vol. 29 No. 5, pp. 1354-1371.

Ndubisi, N.O., Nygaard, A. and Gibson, C.N. (2020), "Managing sustainability tensions in global supply chains: specific investments in closed-loop technology vs "blood metals", Production Planning and Control, Vol. 31 Nos 11-12, pp. 1005-1013.

Newton, T. and Harte, G. (1997), “Green business: technicist kitsch?”, Journal of Management Studies, Vol. 34 No. 1, pp. 75-98.

Niu, B., Peng, S., Li, C., Liang, Q., Li, X. and Wang, Z. (2020), "Nexus of embodied land use and greenhouse gas emissions in global agricultural trade: a quasi-input-output analysis", Journal of Cleaner Production, Vol. 267, p. 122067.

Norman, W. and MacDonald, C. (2004), "Getting to the bottom of 'riple bottom line", Business Ethics Quarterly, Vol. 14 No. 2, pp. 243-262.

Oosterveer, P., Adjei, B.E., Vellema, S. and Slingerland, M. (2014), "Global sustainability standards and food security: exploring unintended effects of voluntary certification in palm oil", Global Food Security, Vol. 3 Nos 3-4, pp. 220-226.

Pagell, M. and Shevchenko, A. (2014), "Why research in sustainable supply chain management should have no future", Journal of Supply Chain Management, Vol. 50 No. 1, pp. 44-55.

Pingali, P.L. (2012), "Green Revolution: impacts, limits, and the path ahead", Proceedings of the National Academy of Sciences, Vol. 109 No. 31, pp. 12302-12308.

Rabbani, M., Saravi, N.A., Farrokhi-Asl, H., Lim, S.F.W.T. and Tahaei, Z. (2018), "Developing a sustainable supply chain optimization model for switchgrass-based bioenergy production: a case study”, Journal of Cleaner Production, Vol. 200, pp. 827-843.

Reiner, G., Gold, S. and Hahn, R. (2015), "Wealth and health at the Base of the Pyramid: modelling trade-offs and complementarities for fast moving dairy product case", International Journal of Production Economics, Vol. 170 B Part, pp. 413-421.

Rodríguez, J.A., Giménez, C., Arenas, D. and Pagell, M. (2016), "NGOs' initiatives to enhance social sustainability in the supply chain: poverty alleviation through supplier development programs", Journal of Supply Chain Management, Vol. 52 No. 3, pp. 83-108.

Saleh, N. (2009), "Philosophical pitfalls: the methods debate in American political science", Journal of Integrated Social Sciences, Vol. 1 No. 1, pp. 141-76.

Sarkis, J. (2020), "Supply chain sustainability: Learning from the COVID-19 pandemic", International Journal of Operations and Production Management, accepted for publication, doi: 10.1108/IJOPM08-2020-0568.

Saunders, L.W., Brooks, J.P., Merrick, J.R.W. and Autry, C.W. (2020), "Addressing economic/ environmental sustainability trade-offs in procurement episodes with industrial suppliers", Production and Operations Management, Vol. 29 No. 5, pp. 1256-1269.

Scarlat, N. and Dallemand, J.F. (2011), "Recent developments of biofuels/bioenergy sustainability certification: a global overview”, Energy Policy, Vol. 39 No. 3, pp. 1630-1646. 
Scherer, A.G. and Voegtlin, C. (2020), "Corporate governance for responsible innovation: approaches to corporate governance and their implications for sustainable development", Academy of Management Perspectives, Vol. 34 No. 2, pp. 182-208.

Schleifer, P. and Sun, Y. (2020), "Reviewing the impact of sustainability certification on food security in developing countries", Global Food Security, Vol. 24, p. 100337.

Schleper, M.C., Blome, C. and Wuttke, D.A. (2017), "The dark side of buyer power: supplier exploitation and the role of ethical climates", Journal of Business Ethics, Vol. 140 No. 1, pp. 97-114.

Schmidt, C.G., Foerstl, K. and Schaltenbrand, B. (2017), "The supply chain position paradox: green practices and firm performance", Journal of Supply Chain Management, Vol. 53 No. 1, pp. 3-25.

Scott, A., Balthrop, A. and Miller, J.W. (2020), "Unintended responses to IT-enabled monitoring: the case of the electronic logging device mandate", Journal of Operations Management, Vol. aheadof-print No. ahead-of-print. doi: 10.1002/joom.1110.

Shevchenko, A., Lévesque, M. and Pagell, M. (2016), "Why firms delay reaching true sustainability", Journal of Management Studies, Vol. 53 No. 5, pp. 911-935.

Siltaloppi, J., Rajala, R. and Hietala, H. (2020), "Integrating CSR with business strategy: a tension management perspective", Journal of Business Ethics, Vol. ahead-of-print No. ahead-of-print. doi: 10.1007/s10551-020-04569-3.

Silvestre, B.S., Viana, F.L.E. and Sousa Monteiro, M.d. (2020), "Supply chain corruption practices circumventing sustainability standards: wolves in sheep's clothing", International Journal of Operations \& Production Management, Vol. ahead-of-print No. ahead-of-print. doi: 10.1108/ IJOPM-06-2019-0454.

Simon, H.A. (1962), "The Architecture of Complexity", Proceedings of the American Philosophical Society, Vol. 106 No 6, pp. 467-482.

Stigler, G.J. (1975), The Citizen and the State: Essays on Regulation, University of Chicago Press, Chicago, Vol. 834.

Tachizawa, E. and Wong, Y. (2014), "Towards a theory of multi-tier sustainable supply chains: a systematic literature review”, Supply Chain Management: An International Journal, Vol. 19 Nos 5-6, pp. 643-663.

Tan, K.H., Chung, L., Shi, L. and Chiu, A. (2017), "Unpacking the indirect effects and consequences of environmental (reprint)", International Journal of Production Economics, Vol. 190, pp. 22-30.

Tencati, A., Russo, A. and Quaglia, V. (2008), "Unintended consequences of CSR: protectionism and collateral damage in global supply chains: the case of Vietnam", Corporate Governance, Vol. 8 No. 4, pp. 518-531.

Towers, N., Abushaikha, I., Ritchie, J. and Holter, A. (2020), "The impact of phenomenological methodology development in supply chain management research", Supply Chain Management: An International Journal, Vol. 25 No. 4, pp. 443-456.

Trautrims, A., Schleper, M.C., Cakir, M.S. and Gold, S. (2020), "Survival at the expense of the weakest? Managing modern slavery risks in supply chains during COVID-19", Journal of Risk Research, Vol 23 No 7/8, pp. 1067-1072.

Tuni, A., Rentizelas, A. and Chinese, D. (2020), "An integrative approach to assess environmental and economic sustainability in multi-tier supply chains", Production Planning and Control, Vol. 31 Nos 11-12, pp. 861-882.

Ugarte, G.M., Golden, J.S. and Dooley, K.J. (2016), "Lean versus green: the impact of lean logistics on greenhouse gas emissions in consumer goods supply chains", Journal of Purchasing and Supply Management, Vol. 22 No. 2, pp. 98-109.

Van der Byl, C.A. and Slawinski, N. (2015), "Embracing tensions in corporate sustainability: a review of research from win-wins and trade-Offs to paradoxes and beyond", Organization and Environment, Vol. 28 No. 1, pp. 54-79. 
IJOPM

40,12

Vanpoucke, E., Vereecke, A. and Wetzels, M. (2014), "Developing supplier integration capabilities for sustainable competitive advantage: a dynamic capabilities approach", Journal of Operations Management, Vol. 32 Nos 7-8, pp. 446-461.

Varsei, M., Soosay, C., Fahimnia, B. and Sarkis, J. (2014), "Framing sustainability performance of supply chains with multidimensional indicators", Supply Chain Management: An International Journal, Vol. 19 No. 3, pp. 242-257.

Verghese, A., Shah, N.H. and Harrington, R.A. (2018), "What this computer needs is a physician: humanism and artificial intelligence”, Jama, Vol. 319 No. 1, pp. 19-20.

Villena, V.H. (2019), "The missing link? The strategic role of procurement in building sustainable supply networks", Production and Operations Management, Vol. 28 No. 5, pp. 1149-1172.

Wannags, L.L. and Gold, S. (2020), "Assessing tensions in corporate sustainability transition: from a review of the literature towards an actor-oriented management approach", Journal of Cleaner Production, Vol. 264, p. 121662.

Williamson, O.E. (1993), “Calculativeness, trust, and economic organization”, The Journal of Law and Economics, Vol. 36 No. 1, Part 2, pp. 453-486.

Wontner, K.L., Walker, H., Harris, I. and Lynch, J. (2020), "Maximising 'Community Benefits' in public procurement: tensions and trade-offs", International Journal of Operations \& Production Management, Vol. ahead-of-print No. ahead-of-print. doi: 10.1108/IJOPM-05-2019-0395.

WSP (2020), "Office vs home working: how we can save our carbon footprint", WSP.com, (20 February 2020), available at: www.wsp.com/en-GB/insights/office-vs-home-working-how-we-can-saveour-carbon-footprint (accessed 31 October 2020).

Wurzer, T. and Reiner, G. (2018), "Evaluating the impact of modular product design on flexibility performance and cost performance with delivery performance as a moderator", International Journal of Operations and Production Management, Vol. 38 No. 10, pp. 1987-2008.

Xiao, C., Wilhelm, M., van der Vaart, T. and Van Donk, D.P. (2019), "Inside the buying firm: exploring responses to paradoxical tensions in sustainable supply chain management", Journal of Supply Chain Management, Vol. 55 No. 1, pp. 3-20.

Ye, Y., Yeung, A.C.L. and Huo, B. (2020), "Maintaining stability while boosting growth? The long-term impact of environmental accreditations on firms' financial risk and sales growth", International Journal of Operations \& Production Management, Vol. ahead-of-print No. ahead-of-print. doi: 10. 1108/IJOPM-05-2019-0407.

Zahiri, B., Zhuang, J. and Mohammadi, M. (2017), “Toward an integrated sustainable-resilient supply chain: a pharmaceutical case study", Transportation Research Part E: Logistics and Transportation Review, Vol. 103, pp. 109-142.

Zarei, M.H., Carrasco-Gallego, R. and Ronchi, S. (2019), "To greener pastures: an action research study on the environmental sustainability of humanitarian supply chains", International Journal of Operations and Production Management, Vol. 39 No. 11, pp. 1193-1225.

\section{Corresponding author}

Jeremy K. Hall can be contacted at: jeremy.k.hall@sussex.ac.uk

For instructions on how to order reprints of this article, please visit our website:

www.emeraldgrouppublishing.com/licensing/reprints.htm

Or contact us for further details: permissions@emeraldinsight.com 